\title{
Depleting Groundwater Levels And Increasing Fluoride Concentration In Villages Of Surajpur District, Chhattisgarh, India: Cost To Economy And Health.
}

\author{
Dr. Manish Upadhyay \\ HOD \& Associate Professor, Dr.C.V.Raman University Kargi Road,KotaBilaspur (C.G)
}

\begin{abstract}
Although fluoride was once considered an essential nutrient, the U.S. National Research Council has since removed this designation due to the lack of studies showing it is essential for human growth, though still considering fluoride a "beneficial element" due to its positive impact on oral health. The U.S. specifies the optimal level of fluoride to range from 0.7 to $1.2 \mathrm{mg} / \mathrm{L}$ (milligrams per liter, equivalent to parts per million), depending on the average maximum daily air temperature; the optimal level is lower in warmer climates, where people drink more water, and is higher in cooler climates The U.S. standard, adopted in 1962, is not appropriate for all parts of the world and is based on assumptions that have become obsolete with the rise of air conditioning and increased use of soft drinks, processed food, and other sources of fluorides. In 1994 a World Health Organization expert committee on fluoride use stated that $1.0 \mathrm{mg} / \mathrm{L}$ should be an absolute upper bound, even in cold climates, and that $0.5 \mathrm{mg} / \mathrm{L}$ may be an appropriate lower limit A 2007 Australian systematic review recommended a range from 0.6 to $1.1 \mathrm{mg} / \mathrm{L}$.
\end{abstract}

A 2000 systematic review found that water fluoridation was statistically associated with a decreased proportion of children with cavities (the median of mean decreases was $14.6 \%$, the range -5 to $64 \%$ ), and with a decrease in decayed, missing, and filled primary teeth (the median of mean decreases was 2.25 teeth, the range 0.5-4.4 teeth), which is roughly equivalent to preventing 40\% of cavities. The review found that the evidence was of moderate quality: many studies did not attempt to reduce observer bias, control for confounding factors, report variance measures, or use appropriate analysis. Although no major differences between natural and artificial fluoridation were apparent, the evidence was inadequate to reach a conclusion about any differences. Fluoride also prevents cavities in adults of all ages. There are fewer studies in adults however, and the design of water fluoridation studies in adults is inferior to that of studies of self- or clinically applied fluoride. A 2007 meta-analysis found that water fluoridation prevented an estimated $27 \%$ of cavities in adults (95\% confidence interval [CI] 19-34\%), about the same fraction as prevented by exposure to any delivery method of fluoride (29\% average, 95\% CI: 16-42\%). A 2002 systematic review found strong evidence that water fluoridation is effective at reducing overall tooth decay in communities.

Fluoride's adverse effects depend on total fluoride dosage from all sources. At the commonly recommended dosage, the only clear adverse effect is dental fluorosis, which can alter the appearance of children's teeth during tooth development; this is mostly mild and is unlikely to represent any real effect on aesthetic appearance or on public health. ${ }^{[10]}$ The critical period of exposure is between ages one and four years, with the risk ending around age eight. Fluorosis can be prevented by monitoring all sources of fluoride, with fluoridated water directly or indirectly responsible for an estimated $40 \%$ of risk and other sources, notably toothpaste, responsible for the remaining $60 \%$. Compared to water naturally fluoridated at $0.4 \mathrm{mg} / \mathrm{L}$, fluoridation to $1 \mathrm{mg} / \mathrm{L}$ is estimated to cause additional fluorosis in one of every 6 people (95\% CI 4-21 people),

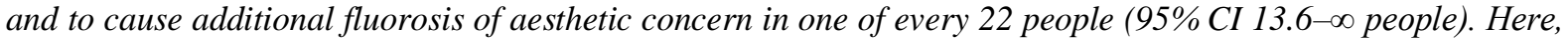
aesthetic concern is a term used in a standardized scale based on what adolescents would find unacceptable, as measured by a 1996 study of British 14-year-olds In many industrialized countries the prevalence of fluorosis is increasing even in unfluoridated communities, mostly because of fluoride from swallowed toothpaste. A 2009 systematic review indicated that fluorosis is associated with consumption of infant formula or of water added to reconstitute the formula, that the evidence was distorted by publication bias, and that the evidence that the formula's fluoride caused the fluorosis was weak.. In the U.S. the decline in tooth decay was accompanied by increased fluorosis in both fluoridated and unfluoridated communities; accordingly, fluoride has been reduced in various ways worldwide in infant formulas, children's toothpaste, water, and fluoride-supplement schedules

Key Word: Fluoridation, dosage,fluorosis, aesthetic,consumption.

\section{Introduction}

Safe drinking water is essential to humans and other life forms. Access to safe drinking water has improved over the last decades in almost every part of the world, but approximately one billion people still lack access to safe water and over 2.5 billion lack access to adequate sanitation. There is a clear correlation between 
access to safe water and GDP per capita. However, some observers have estimated that by 2025 more than half of the world population will be facing water-based vulnerability. A recent report (November 2009) suggests that by 2030 , in some developing regions of the world, water demand will exceed supply by $50 \%$. Water plays an important role in the world economy, as it functions as a solvent for a wide variety of chemical substances and facilitates industrial cooling and transportation. Approximately $70 \%$ of the fresh water used by humans goes to agriculture .Water is the chemical substance with chemical formula $\mathrm{H}_{2} \mathrm{O}$ : one molecule of water has two hydrogen atoms covalently bonded to a single oxygen atom. Water appears in nature in all three common states of matter and may take many different forms on Earth: water vapor and clouds in the sky; seawater and icebergs in the polar oceans; glaciers and rivers in the mountains; and the liquid in aquifers in the ground.At high temperatures and pressures, such as in the interior of giant planets, it is argued that water exists as ionic water in which the molecules break down into a soup of hydrogen and oxygen ions, and at even higher pressures as superionic water in which the oxygen crystallises but the hydrogen ions float around freely within the oxygen lattice. Fluoride's effects depend on the total daily intake of fluoride from all sources. About 70-90\% of ingested fluoride is absorbed into the blood, where it distributes throughout the body. In infants 80-90\% of absorbed fluoride is retained, with the rest excreted, mostly via urine; in adults about $60 \%$ is retained. About $99 \%$ of retained fluoride is stored in bone, teeth, and other calcium-rich areas, where excess quantities can cause fluorosis. Drinking water is typically the largest source of fluoride. In many industrialized countries swallowed toothpaste is the main source of fluoride exposure in unfluoridated communities. Other sources include dental products other than toothpaste; air pollution from fluoride-containing coal or from phosphate fertilizers; trona, used to tenderize meat in Tanzania; and tea leaves, particularly the tea bricks favored in parts of China. High fluoride levels have been found in other foods, including barley, cassava, corn, rice, taro, yams, and fish protein concentrate. The U.S. Institute of Medicine has established Dietary Reference Intakes for fluoride: Adequate Intake values range from $0.01 \mathrm{mg} /$ day for infants aged 6 months or less, to $4 \mathrm{mg} /$ day for men aged 19 years and up; and the Tolerable Upper Intake Level is $0.10 \mathrm{mg} / \mathrm{kg} / \mathrm{day}$ for infants and children through age 8 years, and $10 \mathrm{mg} /$ day thereafter.

\section{Objectives Of The Present Work}

The quality of water is of vital concern for mankind since it is directly linked with human welfare. It is matter of history that faecal pollution of drinking water caused water bourne diseases which wiped out entire population of cities.

The aim of this study was to determine the amount of fluoride in drinking water of Five villages of Premnagar Block of Surajpur dist.

Polluted water is the culprit in all such cases. The major sources of water pollution are domestic waste from urban and rural areas, and industrial wastes which are discharged in to natural water bodies.For this Physico-chemical analysis of drinking water samples will be taken from different Five villages of block Premnagar and awares to avoid all problem which come from more fluoride.

Because presence of large amount of fluoride is associated with---

\# Dental and skeletal fluorosis and inadequate amount with dental carries.

\# U S public health services has stated that fluoride makes the bone more brittle.

\# Mottling of teeth disease causes permanent damage to the enamel.

\# Skeletal fluorosis followed by pain and stiffless of the joints.

\# Osteoporosis found children below age of 10 years also affected.

\# In female faces infertility problem.

\section{Introduction of selected area}

Surajpur (newly formed dist. of Sarguja division), with an area of 16034.4 Sq.kms with 54 percent of tribal population is one of the under developed districts in Chhattisgarh. About 36\% of area encompasses reserved and protected forest land. Ambikapur is the district headquarters. The total population of the district is 1970661 (2001) census, out of which $93.03 \%$ is rural population. The net irrigated area is 31968 ha. out of which 6077 ha. (19 percent only) is irrigated by ground water

Sarguja district is a great table land of numerous hills and plateau.The two important Physiographic features of the district are the Mainpat plateau and the Jamirpat plateau.The former is $28.8 \mathrm{~km}$ long and $12.8 \mathrm{~km}$ wide and rises to a maximum height of 1152.45 metres. It forms the southern boundary with Raigarh district. The Jamirpat is about $3 \mathrm{~km}$ wide. It forms the eastern boundary of Sarguja with Jharkhand State. The maximum elevation of Jamirpat is 1219.2 metres. The principal rivers of the district are the Kanhar, the Rihand, the Morna, the Mahan, the Geur, the Geger, the Neur, and the Gej. There are two distinct drainage system in the district. One is northernly and the other is southernly.

The district has subtropical climate characterised by hot summer and monsoon rainfall followed by dry and cold winter season. The normal rainfall of the district is $1600.9 \mathrm{~mm}$. The annual temperature varies from $39.6^{\circ} \mathrm{C}$ to $43^{\circ} \mathrm{C}$ in summer and $8.6^{\circ}$ to $23.9^{\circ} 8 \mathrm{C}$ in winter. 


\section{Hydrogeology}

The major geological formations in the district are rocks belonging to Archean, Gondwanas, Lametas and Deccan trap group of rocks overlain by sub Recent to Recent alluvial sediments. Ground water occurs under phreatic and semi confined to confined conditions in the intergrannular pore spaces in the shallow weathered rocks and in the fractured system at deeper levels respectively. The ground water levels in the phreatic aquifer varies from 3.66 to $16.5 \mathrm{mbgl}$ and from 1.59 to $10.37 \mathrm{mbgl}$ during pre monsoon and post monsoon period respectivly. Long term trend analysis of ground water level in the district reveals that $13.15 \%$ of the wells in pre monsoon and none of the wells in post monsoon period show a significant $(20 \mathrm{~cm} / \mathrm{year})$ falling trend.

Under the exploration programme, the Central Ground Water Board (CGWB) has drilled 30 exploratory in the Sarguja district to assess the aquifer system and their potential. The data from these boreholes has indicated that the aquifers vary from few metres to $70 \mathrm{mbgl}$. Tube wells in Gondwanas range from 27 to 76 mbgl. with discharge between 5 to $3 \mathrm{~m}^{3} / \mathrm{hr}$. The ground water in the district is mainly developed by dug wells for domestic and irrigation purposes. The dug cum bore wells are also used for irrigation. These structures tap ground water down to a depth of 6 to $20 \mathrm{mbgl}$. The borewells fitted with hand pumps are used for the rural drinking water supply requirements of the village community.

\section{Quality}

The quality of ground water in the district is generally suitable for both drinking and irrigation and is within the permissible limits as per Indian Standards.

\section{Water Table Condition}

Decadal (1995-2005) Average of Pre-monsoon (May) Water Level in m

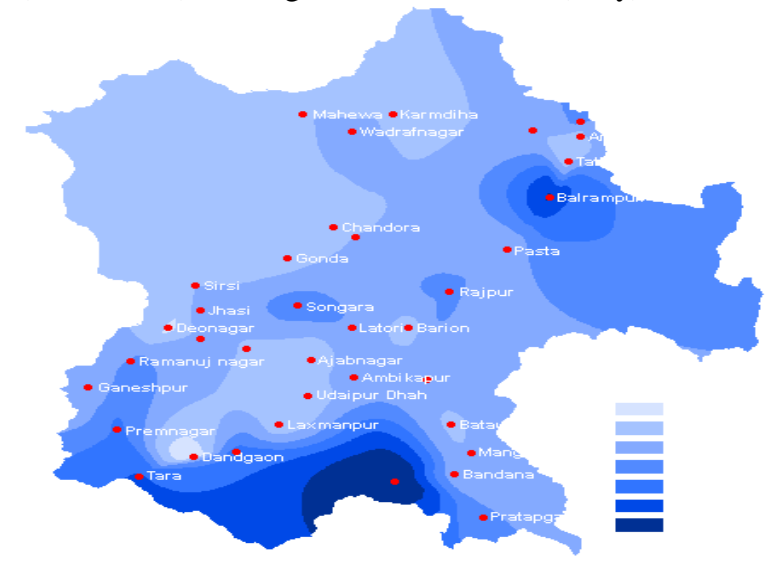

\section{Ground Water Resources}

Ground water resource figures presented below are as per the estimations carried out jointly by CGWB,Govt. of India and Ground Water Survey Circle, Govt. of Chhattisgarh. The figures pertain to the year 2004.All the blocks in the district have been categorised as safe from ground water development point of view.

\begin{tabular}{|c|c|}
\hline $\begin{array}{l}\text { Annual Available Ground Water Resources } \\
\text { (ha m) }\end{array}$ & 154455 \\
\hline $\begin{array}{l}\text { Allocation for Domestic Use in the year } 2025 \\
\text { (ha m) }\end{array}$ & 7302 \\
\hline Gross Draft for Irrigation (ha m) & 26326 \\
\hline $\begin{array}{l}\text { Balance Ground Water Availability for Future } \\
\text { Irrigation (ha m) }\end{array}$ & 120827 \\
\hline Stage of Ground Water Development (\%) & 20.05 \\
\hline $\begin{array}{l}\text { Additional Area that can be Brought Under } \\
\text { Irrigation (ha) } \\
\text { (assuming } 90 \% \text { stage of development and crop } \\
\text { water requirement of } 0.7 \mathrm{~m} \text { ) }\end{array}$ & $\begin{array}{l}73550 \\
(4.3 \% \text { of the } \\
\text { geographical area })\end{array}$ \\
\hline
\end{tabular}




\section{Material \& Method}

Samples were collected and analysed as per procedure laid down in the standard methods for examination of water and waste water of American public Health Association (APHA) compsite sampling method was adopted for collection of samples of water from five location of village Sample for chemical analysis were collected in polyethylene container's. Samples collected for metal contents were acitified $(1.0 \mathrm{ml}$ $\mathrm{HNO}_{3}$ per liter samples). Some of the parameter like $\mathrm{P}^{\mathrm{H}}$ Temperature, conductivity, dissolve oxygen T.D.S. were analysed on site using portable water analysis kit. The other parameter were analysed at laboratory.

Method: SPADNS SPECTROPHOTOMETRIC

Apparatus

a. Distillation apparatus: 1L round bottom long neck, borosilicate glass boiling flask, thermometer adapter, connecting tube and an efficient condenser, with thermometer adapter and a thermometer reading up to $200 \mathrm{oC}$, The apparatus is shown in the Figure.

Alternative types of distillation apparatus may be used.

b. Spectrophotometer for use at $570 \mathrm{~nm}$. It must provide a light path of at least $1 \mathrm{~cm}$ or a spectrophotometer with a greenish yellow filter (550 to $580 \mathrm{~nm}$ ).

Reagents

a. Sulphuric acid, $\mathrm{H} 2 \mathrm{SO} 4$, conc., reagent grade

b. Silver sulphate, $\mathrm{Ag} 2 \mathrm{SO} 4$, crystals, reagent grade

c. Stock fluoride solution. Dissolve 221.0mg anhydrous sodium fluoride, $\mathrm{NaF}$, in distilled water and dilute to $1000 \mathrm{~mL} ; 1 \mathrm{~mL}=100 \mu \mathrm{g}$ Fd.

Standard fluoride solution. Dilute $100 \mathrm{~mL}$ stock fluoride solution to $1000 \mathrm{~mL}$ with distilled water; $1 \mathrm{~mL}=10 \mu \mathrm{g}$ Fe.

SPADNS solution: Dissolve 958mg SPADNS, sodium 2 - (parasulphophenylazo)-1,8 - dihydroxy-3,6naphthalenedisulphonate, in distilled water and dilute to $500 \mathrm{~mL}$; protect from light - stable for 1 year.

f. Zirconyl-acid reagent: Dissolve 133mg zirconyl chloride octahydrate, $\mathrm{ZrOCl} 2.8 \mathrm{H} 2 \mathrm{O}$, in about $25 \mathrm{~mL}$ distilled water, add $350 \mathrm{~mL}$ conc $\mathrm{HCl}$ and dilute to $500 \mathrm{~mL}$.

g. Mixed acid zirconyl-SPADNS reagent: Mix equal volumes of SPADNS solution and zirconyl-acid reagent stable for 2 years.

h. Reference solution: Add $10 \mathrm{~mL}$ SPADNS solution to $100 \mathrm{~mL}$ distilled water. Dilute $7 \mathrm{mLconc} \mathrm{HCl}$ to $10 \mathrm{~mL}$ with distilled water and add to SPADNS solution - stable for 1 year. Set the instrument to zero with this solution.

i. Sodium arsenite solution: Dissolve $5 \mathrm{~g} \mathrm{NaAsO} 2$ and dilute to $1 \mathrm{~L}$ with distilled water

\section{Procedure}

a. Distillation: Distillation is necessary for samples containing high concentration of dissolved solids, see Table. Proceed to step d if distillation is not required. To $400 \mathrm{Ml}$ distilled water in the distillation flask, with magnetic stirrer operating, add $200 \mathrm{~mL}$ conc. $\mathrm{H} 2 \mathrm{SO} 4$ and a few glass beads. Connect the apparatus as shown in the figure and heat to Laboratory Manual ID: 1.11 Version: 2 Page: $2 / 3$

$180^{\circ} \mathrm{C}$. Prevent overheating by stopping heating when temperature reaches $178^{\circ} \mathrm{C}$.

Discard distillate.

b. Cool the acid mixture remaining in the flask to $80 \mathrm{oC}$ and add $300 \mathrm{~mL}$ sample. With stirrer operating, distil until the temperature reaches $180 \mathrm{oC}$ (again stop heating at $178 \mathrm{oC}$ to prevent overheating), turn off heat; retain the distillate for analysis.

c. Add $\mathrm{AgSO}_{4}$ to the distilling flask at the rate of $5 \mathrm{mg} / \mathrm{mg} \mathrm{Cl}$ - to avoid Cl- interference. $\mathrm{H} 2 \mathrm{SO} 4$ solution in the flask can be used repeatedly until contaminant from samples accumulates to such an extent that recovery is affected. This can be ascertained by distilling a known standard and determining recovery.

d. Standard Curve Preparation: Take the following volumes of standard fluoride solution and dilute to $50 \mathrm{~mL}$ with distilled water and note down the temperature:

Standard F-solution, $\mathrm{mL}$ 0 0.1 0.2 0.5 1.0 2.0 3.0 5.0 7.0

$\mu \mathrm{g}$ F- 0 1.0 2.0 5.0 10.0 20.0 30.0 50.0 70.0

e. Pipette $10.00 \mathrm{~mL}$ of mixed acid-zirconyl-SPADNS reagent to each standard and mix well. Avoid contamination. Set photometer to zero absorbance with the reference solution and obtain absorbance readings of standards (at 570nm). Plot a curve of mg F- versus absorbance. Prepare a new standard curve whenever a fresh reagent or a different standard temperature is used. 
Village I - Baraul

\section{VI. $\quad$ Result \& Disscussion}

A Total number of six samples were collected and tested for their fluoride concentration. Three samples represent surface water collected from river/nallah and represented as $\mathrm{s} 1-\mathrm{sw}_{1}, \mathrm{~s} 2-\mathrm{sw}_{2}, \mathrm{~s} 3-\mathrm{sw}_{3}$ while the remaining samples were collected from under-ground water / tube wells $\mathrm{s} 4-\mathrm{sw}_{4}, \mathrm{~s} 5-\mathrm{sw}_{5}, \mathrm{s6}-\mathrm{sw}_{6}$. All the six samples were colourless . odourless, and free from solid suspension. The result of absorbance have been compiled below for the se samples:-

Table I- Fluoride Concentration of water samples in village Baraul

\begin{tabular}{|l|l|}
\hline samples & Fluoride in $\mathrm{mg} / \mathrm{l}$ \\
\hline $\mathrm{s} 1-\mathrm{sw}_{1}$ & 2.40 \\
\hline $\mathrm{s} 1-\mathrm{sw}_{2}$ & 2.80 \\
\hline $\mathrm{s} 1-\mathrm{sw}_{3}$ & 3.50 \\
\hline $\mathrm{s} 1-\mathrm{sw}_{4}$ & 2.50 \\
\hline $\mathrm{s} 1-\mathrm{sw}_{5}$ & 3.0 \\
\hline $\mathrm{s} 1-\mathrm{sw}_{6}$ & 3.0 \\
\hline
\end{tabular}

\section{Village II Ramtirath}

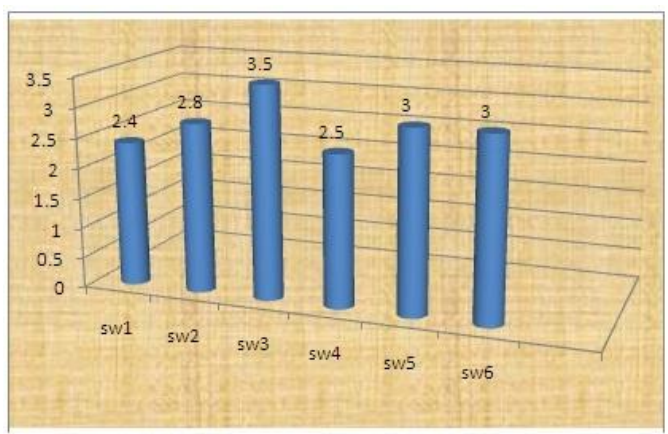

A Total number of six samples were collected and tested for their fluoride concentration. Three samples represent surface water collected from river/nallah and represented as $\mathrm{s} 1-\mathrm{sw}_{1}, \mathrm{~s} 2-\mathrm{sw}_{2}, \mathrm{~s} 3-\mathrm{sw}_{3}$ while the remaining samples were collected from under-ground water / tube wells $\mathrm{s} 4-\mathrm{sw}_{4}, \mathrm{~s} 5-\mathrm{sw}_{5}, \mathrm{~s}-\mathrm{sw}_{6}$. All the six samples were colourless . odourless, and free from solid suspension. The result of absorbance have been compiled below for these samples:-

Table II- Fluoride Concentration of water samples in village Ramtirath

\begin{tabular}{|l|l|}
\hline samples & Fluoride in $\mathrm{mg} / \mathrm{l}$ \\
\hline $\mathrm{S} 2-\mathrm{Sw}_{1}$ & 2.44 \\
\hline $\mathrm{S} 2-\mathrm{sw}_{2}$ & 2.60 \\
\hline $\mathrm{S} 2-\mathrm{sw}_{3}$ & 3.0 \\
\hline $\mathrm{S} 2-\mathrm{sw}_{4}$ & 2.50 \\
\hline $\mathrm{S} 2-\mathrm{sw}_{5}$ & 2.50 \\
\hline $\mathrm{S} 2-\mathrm{Sw}_{6}$ & 2.16 \\
\hline
\end{tabular}

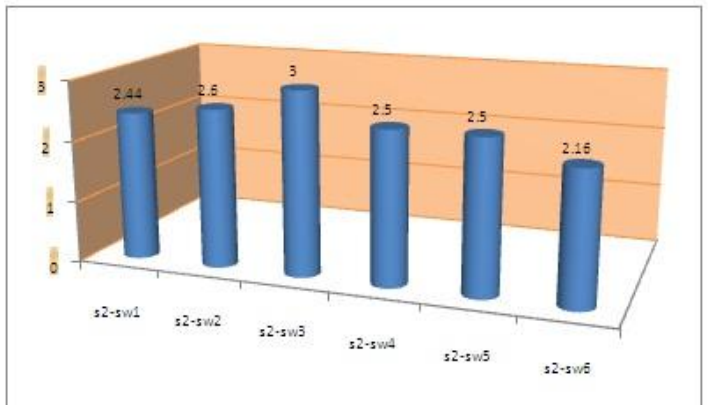

\section{Village III- BANAPATTI}

Water samples

A Total number of six samples were collected and tested for their fluoride concentration. Three samples represent surface water collected from river/nallah and represented as $\mathrm{s} 3-\mathrm{sw}_{1}, \mathrm{~s} 3-\mathrm{sw}_{2}, \mathrm{~s} 3-\mathrm{sw}_{3}$ while the remaining samples were collected from under-ground water / tube wells $\mathrm{s} 3-\mathrm{sw}_{4}, \mathrm{~s} 3-\mathrm{sw}_{5}, \mathrm{~s} 3-\mathrm{sw}_{6}$. All the six 
Depleting Groundwater Levels and Increasing Fluoride Concentration in Villages of Surajpur samples were colourless . odourless, and free from solid suspension. The result of absorbance have been compiled below for these samples:-

Table III- Fluoride Concentration of water samples in village BANAPATTI

\begin{tabular}{|l|l|}
\hline samples & Fluoride in $\mathrm{mg} / \mathrm{l}$ \\
\hline $\mathrm{S} 3-\mathrm{sw}_{1}$ & 2.05 \\
\hline $\mathrm{S} 3-\mathrm{sw}_{2}$ & 3.00 \\
\hline $\mathrm{S} 3-\mathrm{Sw}_{3}$ & 3.10 \\
\hline $\mathrm{S} 3-\mathrm{Sw}_{4}$ & 3.55 \\
\hline $\mathrm{S} 3-\mathrm{Sw}_{5}$ & 3.40 \\
\hline $\mathrm{S} 3-\mathrm{Sw}_{6}$ & 1.90 \\
\hline
\end{tabular}

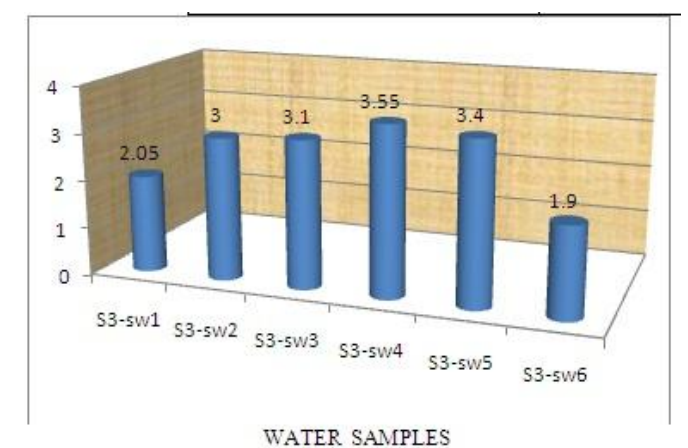

\section{Village IV- BARWAHI}

A Total number of six samples were collected and tested for their fluoride concentration. Three samples represent surface water collected from river/nallah and represented as $\mathrm{s} 5-\mathrm{sw}_{1}, \mathrm{~s} 5-\mathrm{sw}_{2}, \mathrm{~s} 5-\mathrm{sw}_{3}$ while the remaining samples were collected from under-ground water / tube wells $\mathrm{s} 5-\mathrm{sw}_{4}, \mathrm{~s} 5-\mathrm{sw}_{5}, \mathrm{~s} 5-\mathrm{sw}_{6}$. All the six samples were colourless . odourless, and free from solid suspension. The result of absorbance have been compiled below for these samples:-

Table IV- Fluoride Concentration of water samples in village BARWAHI

\begin{tabular}{|l|l|}
\hline samples & Fluoride in $\mathrm{mg} / \mathrm{l}$ \\
\hline $\mathrm{S} 5-\mathrm{sw}_{1}$ & 3.16 \\
\hline $\mathrm{S} 5-\mathrm{Sw}_{2}$ & 3.18 \\
\hline $\mathrm{S} 5-\mathrm{sw}_{3}$ & 2.50 \\
\hline $\mathrm{S}_{3}-\mathrm{sw}_{4}$ & 3.0 \\
\hline $\mathrm{S}_{-}-\mathrm{sw}_{5}$ & 3.50 \\
\hline $\mathrm{S}_{5}-\mathrm{Sw}_{6}$ & 3.20 \\
\hline
\end{tabular}

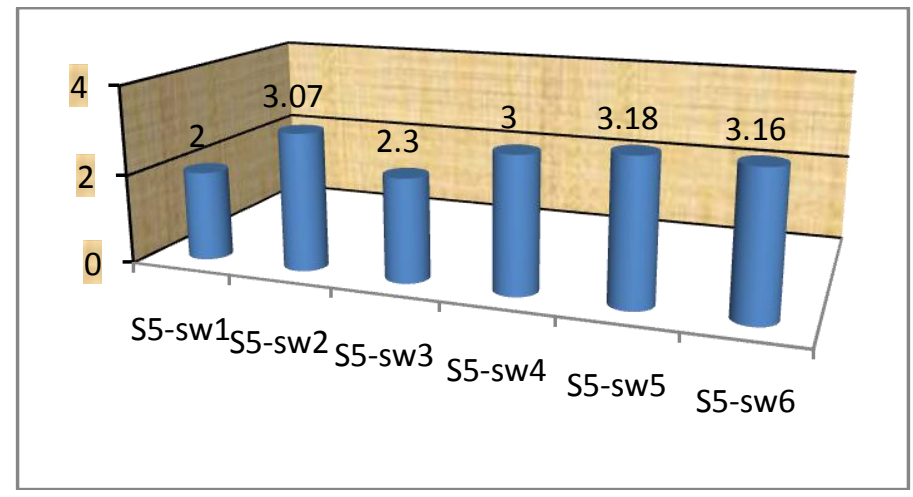

Village VI- FATEHPUR

Water samples

A Total number of six samples were collected and tested for their fluoride concentration. Three samples represent surface water collected from river/nallah and represented as $\mathrm{s} 1-\mathrm{sw}_{1}, \mathrm{~s} 2-\mathrm{sw}_{2}, \mathrm{~s} 3-\mathrm{sw}_{3}$ while the remaining samples were collected from under-ground water / tube wells $\mathrm{s} 4-\mathrm{sw}_{4}, \mathrm{~s} 5-\mathrm{sw}_{5}, \mathrm{s6}-\mathrm{sw}_{6}$. All the six 


\section{Depleting Groundwater Levels and Increasing Fluoride Concentration in Villages of Surajpur}

samples were colourless . odourless, and free from solid suspension. The result of absorbance have been compiled below for these samples:-

Table VI- Fluoride Concentration of water samples in village Fatehpur

\begin{tabular}{|l|l|}
\hline samples & Fluoride in $\mathrm{mg} / \mathrm{l}$ \\
\hline $\mathrm{S}-\mathrm{sw}_{1}$ & 2.0 \\
\hline $\mathrm{S}-\mathrm{Sw}_{2}$ & 3.05 \\
\hline $\mathrm{S}-\mathrm{Sw}_{3}$ & 2.30 \\
\hline S6- $_{4}$ & 3.0 \\
\hline S6- $_{4}$ & 3.50 \\
\hline S6- $_{5}$ & 3.18 \\
\hline
\end{tabular}

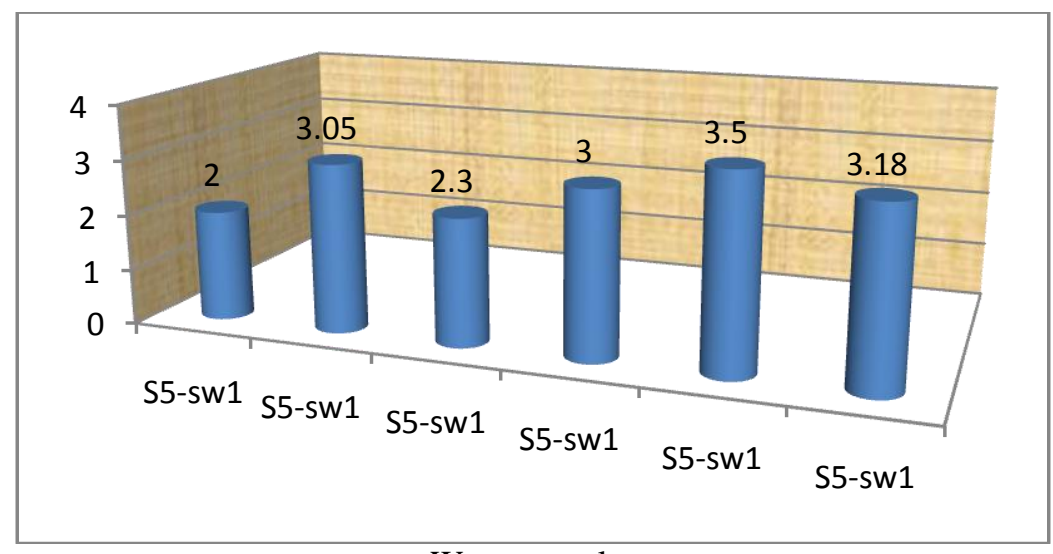

Water samples

Result of analyses of Water from Five villages of Surajpur dist. Of Premnagar Block are recorded in table 1,2,3,4 and 5. In all the five villages each have six sampling station (three were collected from the surface and three samples were collected from the tube well) of village- BARAUL fluoride was recorded in the range of $2.40,2.80,3.50,2.50,3.0$ and $3.0 \mathrm{mg} / \mathrm{l}$. maximum permissible limit for fluoride as world Health organization (WHO) is $1.5 \mathrm{mg} / \mathrm{l}$. all six samples fluoride found excess of their permissible limit.

Water samples analyses of Five villages of Surajpur dist. Of Premnagar Block are recorded in table $1,2,3,4$ and 5. In all the five villages each have six sampling station (three were collected from the surface and three samples were collected from the tube well) of village- BANAPATTI fluoride was recorded in the range of $2.44,2.44,3.0,2.50,2.50$, and $2.16 \mathrm{mg} / 1$. maximum permissible limit for fluoride as Indian standard (IS) is 0.6 to $1.2 \mathrm{mg} / \mathrm{l}$. all six samples fluoride found excess of their permissible limit .

Mximum permissible limit for fluoride as NEERI manual (1991) is $1.0 \mathrm{mg} / \mathrm{l}$. Water from Five villages of Surajpur dist. Of Premnagar Block are recorded in table 1,2,3,4 and 5. In all the five villages each have six sampling station (three were collected from the surface and three samples were collected from the tube well) of village- BARWAHI fluoride was recorded in the range of 2.05, 3.00, 3.10, 3.55, 3.40 and $1.90 \mathrm{mg} / \mathrm{l}$. all six samples fluoride found excess of their permissible limit .

The concentration of fluoride from Five villages are recorded in table. In all the five villages each have six sampling station (three were collected from the surface and three samples were collected from the tube well) of village- DHODHAGAON fluoride was recorded in the range of 3.16, 3.18, 2.50, 3.0, 3.50 and $3.20 \mathrm{mg} / \mathrm{l}$. all six samples fluoride found excess of their permissible limit .Maximum permissible limit for fluoride as NEERI manual (1991) is $1.0 \mathrm{mg} / \mathrm{l}$ and maximum permissible limit for fluoride as world Health organization (WHO) is $1.5 \mathrm{mg} / \mathrm{l}$.

The concentration of fluoride from Five villages are recorded in table . three were collected from the surface and three samples were collected from the tube well of village- FATEHPUR fluoride was recorded in the range of $2.0,3.07,2.30,3.0,3.50$ and $3.18 \mathrm{mg} / \mathrm{l}$. all six samples fluoride found excess of their permissible limit .Maximum permissible limit for fluoride as NEERI manual (1991) is $1.0 \mathrm{mg} / \mathrm{l}$ and maximum permissible limit for fluoride as world Health organization (WHO) is $1.5 \mathrm{mg} / \mathrm{l}$.

\section{Conclusion}

The preset study has been made to evaluate the Fluoride concentration of water samples collected from the Five villages of Premnagar Block of surajpur Dist, Chhattisgarh. Each villages have made six sampling satation.These samples were analysed for study of fluoride and their effect in surrounding area. 
Fluoride in naturally occurring in water can be above or below from recommended levels. Both the excess and deficiency of fluoride in water produces adverse effects on the health.

maximum acceptable limit for fluoride as world Health organization (1985) is $1.5 \mathrm{mg} / \mathrm{l}$. In present study the fluoride concentration of water samples of all Five villages were found over the permissible limit. Therefore, there was harmful effect of fluoride were found in all villages

\section{References}

[1]. Burgstahler AW. Fluoridated bottled water [editorial]. Fluoride 2006;39:252-4.

[2]. Shivarajashankara YM, Shivashankara AR, Rao SH, Bhar PG. Oxidative stress in children with endemic skeletal fluorosis. Fluoride 2001;34:103-7.

[3]. Spittle B. Dyspepsia associated with fluoridated water. Fluoride 2008;41:89-92

[4]. Carton RJ. Review of the 2006 United States National Research Council Report: Fluoride in drinking water. Fluoride 2006;39:16372.

[5]. Susheela AK, Jethanandani P. Circulating testosterone levels in skeletal fluorosis patients. J Toxicol Clin Toxicol 1996;34:183-9.

[6]. Dobaradaran S, Mahvi AH, Dehdashti S, Ranjbar Vakil Abadi D. Drinking water fluoride and child dental caries in Dashtestan, Iran. Fluoride 2008;41:220-6.

[7]. APHA, AWWA, WEF. Standard methods for the examination of water and wastewater. $21^{\text {st }}$ ed. Washington D.C: AWWA; 2005.

[8]. Price JK. Workbook applied math for water plant operators. Lancaster, Pennsylvania: Technomic Pub. Co; 1991.

[9]. Chakraborti D, Chanda CR, Samanta G, Chowdhury UK, Mukherjee SC, Pal AB, et al. Fluorosis in Assam, India. Curr Sci 2000;78:1421-3.

[10]. Karthikeyan K, Nanthakumar K, Velmurugan P, Tamilarasi S, Lakshmanaperumalsamy. Prevalence of certain inorganic constituents in groundwater samples of Erode district, Tamilnadu

[11]. Gupta S, Banerjee S, Saha R, Datta JK, Mondal N. Fluoride geochemistry of groundwater in Nalhati-1 block of the Birbhum district, West Bengal, India. Fluoride 2006;39:318-20.

[12]. Karthikeyan G, Shunmugasundarraj A. Isopleth mapping and in-situ fluoride dependence on water quality in the Krishnagiri block of Tamil Nadu in South India. Fluoride 2000;33:121- 7.

[13]. Williams I. Environmental chemistry. New York: John Wiley \& Sons; 2001

[14]. Mahvi AH, Zazoli MA, Younecian M, Nicpour B, Babapour A. Survey of fluoride concentration in drinking water sources and prevalence of DMFT in the 12 years old students in Behshahr city. J Med Sci 2006;6:658-61.

[15]. Nouri J, Mahvi AH, Babaei A, Ahmadpour E. Regional pattern distribution of groundwater fluoride in the Shush aquifer of Khuzestan County, Iran. Fluoride 2006;39:321-5.

[16]. Mahvi AH, Zazoli MA, Younecian M, Esfandiari Y. Fluoride content of Iranian black tea and tea liquor. Fluoride 2006;39:266-8.

[17]. Hudaykuliyev Y, Tastekin M, Poyrazoglu ES, Baspinar E, Veliogu YS. Variables affecting fluoride in Turkish black tea. Fluoride 2005;38:38-43. 